\title{
ANALISIS KETIMPANGAN PENYERAPAN TENAGA KERJA SEKTOR INDUSTRI PENGOLAHAN DI KABUPATEN/KOTA JAWA TIMUR
}

\author{
Wahyuni Aprilia \\ Sudarti \\ Syamsul Hadi \\ Fakultas Ekonomi dan Bisnis - Universitas Muhammadiyah Malang \\ Email: wahyuniaprilia456@gmail.com
}

\begin{abstract}
This study aims to analyze existence of inequality of employment absorption and determine the effect of the minimum salary, the number of manufacturing industry, and output of manufacturing industry towards inequality of employment absorption of manufacturing industry in regencies/cities of East Java in 20082012. The data collection method uses documentation method. Then, The writer uses the Index Entropy Theil (IET) to measure inequality of employment absorption as dependent variable. Meanwhile, to determine the effect of independent variable toward the dependent variable uses method regression analysis panel data with model common effect approach. The results of this study shows that there are inequality of employment absorption of manufacturing industry in East Java province of the Year 2008-2012. Minimum salary, the number of manufacturing industry, and theoutput of manufacturing industry effect positive and significant effect on inequalityof employment absorption ofmanufacturing industry in regions/cities in East Java.
\end{abstract}

Keywords: Inequality of Employment Absorption.

\begin{abstract}
ABSTRAK
Penelitian ini bertujuan untuk menganalisis terdapat adanya ketimpangan penyerapan tenaga kerja dan mengetahui pengaruh dari upah minimum, jumlah industri pengolahandan output industri pengolahan terhadap ketimpangan penyerapan tenaga kerja industri pengolahan di Kabupaten/kota Jawa Timur tahun 2008-2012. Metode untuk pengumpulan data menggunakan metode dokumentasi.Ketimpangan penyerapan tenaga kerja sebagai variabel terikat yang diukur dengan menggunakan Indeks Entropi Theil (IET). Sedangkan untuk mengetahui pengaruh dari variabel bebas terhadap variabel terikat dengan menggunakan metode analisis regresi data panel dengan pendekatan model common effect. Hasil penelitian menunjukkan bahwa terdapat ketimpangan penyerapan tenaga keraja industri pengolahan di Provinsi Jawa Timur dari Tahun 2008-2012.Upah minimum, jumlah industri pengolahan dan output industri pengolahan berpengaruh positif dan signifikan terhadap ketimpangan penyerapan tenaga kerja industri pengolahan di Kabupaten/kotaJawaTimur.

Kata kunci :Ketimpangan Penyerapan Tenaga Kerja.
\end{abstract}

PENDAHULUAN

Sektor industri dipandang

sebagai sektor yang memiliki tingkat produktivitas yang tinggi, sehingga dengan keunggulan sektor industri akan 
didapat nilai tambah yang tinggi, yang pada akhirnya tujuan menciptakan kesejahteraan masyarakat secara ekonomi lebih cepat terwujud. Kenyataannya tidak semua negara berhasil mengembangkan sektor industrinya yang disebabkan oleh kebijakan yang tidak tepat dan tidak konsisten, sehingga mempengaruhi kinerja sektor industri itu sendiri (Suharto,2002).

Subsektor industri pengolahan, yang meliputi juga industri tenaga (penyediaan air dan listrik), peranannya dalam menciptakan produksi sektor industri dan menampung tenaga kerja pada umumnya menjadi bertambah besar apabila tingkat pembangunan ekonomi menjadi bertambah tinggi. Sub-sektor industri pengolahan merupakan suatu sektor dalam kegiatan ekonomi yang mengalami perkembangan yang pesat sekali dalam proses pembangunan (Sukirno, 1985).

Menurut Dinas Perindustrian dan Perdagangan Jawa Timur tahun 2011, Jawa Timur dikenal sebagai salah satu provinsi di Indonesia yang memiliki posisi strategis, terutama dalam aspek perekonomiannya. Dalam waktu kurun tahun terakhir pertumbuhan ekonomi Jawa Timur stabil diatas rata-rata nasional dengan sektor pertanian dan industri pengolahan sebagai pendorong utama pengggerak perekonomian di Jawa Timur. Dengan dukungan ketersediaan sumber daya manusia yang berkualiatas dan potensi sumberdaya fiskal yang tersedia, baik ditingkat provinsi maupun Kabupaten/Kota, Jawa Timur memiliki peluang besar dalam meningkatkan pertumbuhan ekonomi yang tinggi dan pembangunan yang merata.

Indikator berkembangnya sebuah industri dapat dilihat dari jumlah output yang dihasilkan di 29 Kabupaten dan 9 Kota di Jawa Timur. Di Jawa Timur hanya ada beberapa daerah saja yang bisa menghasilkan output tinggi. Hanya daerah-daerah inti saja yang dapat menghasilkan output yang tinggi karena para investor lebih memilih daerah inti yang sudah tersedia sarana dan fasilitas yang dapat mendukung dengan mudah bagi akses produksinya. Sedangkan daerah pinggiran masih kurangnya sarana dan fasilitas dalam menunjang didirikannya industri dengan skala yang besar.

Menurut Sudarsono dalam Subekti (2007) nilai produksi adalah tingkat produksi atau keseluruhan jumlah barang yang 
merupakan hasil akhir proses produksi pada suatu unit usaha yang selanjutnya akan dijual atau sampai ke tangan konsumen. Apabila permintaan hasil produksi perusahaan atau industri meningkat, produsen cenderung untuk menambah kapasitas produksinya.

Dalam hal ini upah minimum juga mempengaruhi penyerapan tenaga kerja. Konsep upah minimum berarti pekerja akan mendapatkan upah sebesar kebutuhan hidup minimum untuk diri dan keluarganya. Upah minimum di sini tidak termasuk kebutuhan-kebutuhan sosial atau kebutuhan sekunder.Pada awalnya upah minimum ditentukan secara terpusat oleh Departemen Tenaga Kerja untuk region atau wilayahwilayah diseluruh Indonesia. Penentuan besarnya upah minimum dengan memperhatikan faktor-faktor seperti : kemampuan perusahaan, keadaan perekonomian daerah atau nasional, tingkat pengupahan di sektor atau sub sektor yang sama pada wilayah atau propinsi lain, standar kebutuhan hidup pekerja dan keluarga (Haryani, 2002).

Menurut Sukirno (2000:69) bahwa permintaan keatas tenaga kerja merupakan permintaan tidak langsung, maksudnya tenaga kerja dipekerjakan oleh perusahaan dengan tujuan untuk digunakan dalam menghasilkan barang-barang yang mereka jual. Perusahaan akan terus menambah jumlah pekerja selama pekerjaan tambahan tersebut akan menghasilkan penjualan tambahan yang melebihi upah yang dibayarkan kepadanya.

Jumlah Industri di sebuah daerah juga mempunyai peran penting dalam penyerapan teanaga kerja. Industri mempunyai peranan sebagai (leading sector) sektor pemimpin dalam Arsyad (2010:442), maksudnya dengan adanya pembangunan industri maka akan memacu dan mengangkat pembangunan sektor-sektor lainnya.

Semakin banyak jumlah industri yang tersedia maka akan semakin banyak pula penyerapan tenaga kerja. Industri berkaitan erat dengan penyerapan tenaga kerja, dengan adanya jumlah industri atau unit industri yang lebih banyak maka akan menyerap tenaga kerja yang lebih banyak juga karena suatu industri memerlukan tenaga kerja untuk menjalankan proses produksi. Penyerapan tenaga kerja dipengaruhi oleh jumlah unit usaha atau unit industri. Hubungan antara jumlah unit usaha atau unit industri dengan 
jumlah tenaga kerja adalah positif. Semakin meningkatnya jumlah unit usaha atau unit industri, maka akan meningkatkan penyerapan tenaga kerja. Sebaliknya, apabila jumlah unit usaha atau unit industri menurun maka akan mengurangi jumlah tenaga kerja.

Tujuan yang akan dicapai dalam penelitian ini adalah untuk mengetahui adanya ketimpangan penyerapan tenaga kerja industri pengolahan di Kabupaten/Kota Jawa Timur, mengetahui pengaruh upah minimum, jumlah industri pengolahan dan output industri pengolahan terhadap indeks ketimpangan penyerapan tenaga kerja sektor industri pengolahan di Kabupaten/Kota Jawa Timur.

\section{METODE PENELITIAN}

Data yang digunakan dalam penelitian ini adalah data upah minimum, jumlah industri pengolahan, output industri pengolahan dan jumlah tenaga kerja industri pengolahan di Kabupaten/Kota Jawa Timur hasil survey Badan Pusat Statistik (BPS). Tahun yang diamati adalah dari periode 2008-2012.

1. Indeks Entropi Theil
Metode dan alat analisis yang digunakan untuk estimasi dan pengukuran dalam penelitian ini adalah Indeks Theil. Konsep entropi dari suatu distribusi pada dasarnya merupakan aplikasi konsep informasi dalam mengukur kesenjangan ekonomi dan konsentrasi industri. Studi empiris yang dilakukan Theil dengan menggunakan indeks entropi menawarkan pandangan yang tajam mengenai pendapatan regional perkapita dan kesenjangan pendapatan, kesenjangan internasional, dan distribusi produk domestik bruto dunia.

Keunggulan utama indeks ini adalah bahwa pada satu titik waktu, indeks ini menyediakan ukuran derajat konsentrasi ataupun dispersi distribusi spasial pada suatu daerah atau sub daerah dalam suatu negara. Barangkali karakteristik yang paling signifikan dari indeks entropi adalah bahwa indeks ini dapat membedakan kesenjangan antar daerah dan kesenjangan dalam satu daerah. Lebih khusus lagi dalam konteks Jawa Timur, Indeks Theil dapat dinyatakan dalam :

$$
I(y)=\sum \frac{y j}{Y} \times \log \left(\frac{y j}{Y} / \frac{x j}{X}\right)
$$

Dimana : 


$$
\begin{aligned}
\mathrm{I}(\mathrm{y})= & \text { indeks ketimpangan } \\
& \text { penyerapan tenaga kerja } \\
& \text { kabupaten/kota untuk } \\
& \text { seluruh Jawa Timur } \\
\mathrm{yj} / \mathrm{Y}= & \text { jumlah tenaga kerja } \\
& \text { kabupaten/kota dibagi } \\
& \text { rata-rata tenaga kerja } \\
& \text { kabupaten/kota } \\
\mathrm{xj} / \mathrm{X}= & \text { jumlah perusahaan } \\
& \text { kabupaten/kota dibagi } \\
& \text { total jumlah perusahaan } \\
& \text { kabupaten/kota }
\end{aligned}
$$

Indeks entropi Theil pada dasarnya merupakan aplikasi konsep teori informasi dalam mengukur ketimpangan ekonomi dan konsentrasi industri (Kuncoro, 2002). Indeks Entropi Theil tidak memiliki batas atas atau batas bawah, hanya apabila semakin besar nilainya maka semakin timpang dan semakin kecil semakin merata (Kuncoro, 2004).

\section{Regresi Data Panel}

Dalam panel data, data cross section yang sama diobservasi menurut waktu (Gujarati, 2004). Panel data merupakan gabungan antara jenis data time series dan cross section sehingga panel data merupakan data yang memiliki dimensi waktu dan ruang. Beberapa keuntungan dalam menggunakan data panel antara lain:
Heteregonity, lebih informatif, bervariasi, degree of freedom lebih besar dan lebih efisien, menghindari masalah multikolinearitas, lebih unggul dalam mempelajari perubahan dinamis, lebih dapat mendeteksi dan mengukur pengaruh-pengaruh yang tidak dapat diobservasi pada data cross section murni atau time series murni, dapat digunakan untuk mempelajari behavioral model, dan meminimalisasi bias.

Sedangkan bentuk umum dari model regresi panel data dapat dirumuskan dengan persamaan sebagai berikut

$Y_{i t}=\beta_{0}+\beta_{1} X_{1 i t}+\beta_{2} X_{2 i t}+\beta_{3} X_{3 i t}+e_{i t}$

Dimana :

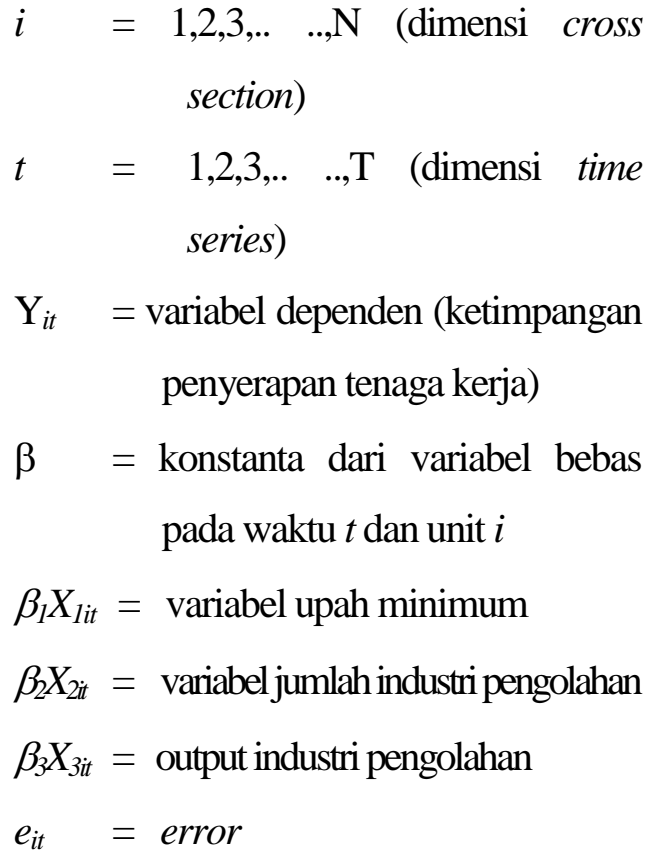


PEMBAHASAN

Analisis Indeks Ketimpangan

Penyerapan Tenaga Kerja Industri

Pengolahan menggunakan Indeks

\section{Entropi Theil.}

Untuk mengetahui adanya ketimpangan tenaga kerja sektor industri pengolahan di Kabupaten/Kota
Jawa Timur, dengan menggunakan Indeks Theil menggunakan software Microsoft Excel. Data yang digunakan merupakan panel data yaitu gabungan cross-section dan time series dengan observasi 5 tahun dari tahun 2008 sampai dengan 2012 yang terdiri 38 Kabupaten/Kota di Provinsi Jawa Timur.

Tabel 1. Ketimpangan Indeks Entropi Theil

\begin{tabular}{lccccc}
\hline & $\mathbf{2 0 0 8}$ & $\mathbf{2 0 0 9}$ & $\mathbf{2 0 1 0}$ & $\mathbf{2 0 1 1}$ & $\mathbf{2 0 1 2}$ \\
\hline Rata-rata & 1,67 & 1,67 & 1,69 & 1,69 & 1,68
\end{tabular}

Sumber: Data diolah menggunakan Indeks Entropi Theil, 2016

Dimana pada tahun 2008 terdapat indeks theil yaitu sebesar 1,67 dan pada tahun 2009 memiliki indeks theil yang sama pada tahun sebelumnya yaitu sebesar 1,67. Pada tahun 2010 terdapat peningkatan keimpangan penyerapan tenaga kerja sektor industri pengolahan di Kabupaten/Kota Jawa Timur yaitu sebesar 1,69 dan pada tahun 2011 mempunyai ketimpangan 1,69 yang sama nilainya dengan tahun sebelumnya. Sementara pada tahun 2012 ketimpangan penyerapan tenaga kerja sector industri pengolahan di kabupaten/Kota Jawa Timur mengalami penurunan dari tahun sebelumnya yaitu sebesar 1,68.
Berdasarkan data yang sudah diolah di atas menunjukkan bahwa pada tahun 2008 sampai pada tahun 2012 terdapat ketimpangan penyerapan tenaga kerja di provinsi Jawa Timur. Indeks entropi Theil pada dasarnya merupakan aplikasi konsep teori informasi dalam mengukur ketimpangan ekonomi dan konsentrasi industri (Kuncoro, 2002). Indeks Entropi Theil tidak memiliki batas atas atau batas bawah, hanya apabila semakin besar nilainya maka semakin timpang dan semakin kecil semakin merata (Kuncoro, 2004).

Analisis Regresi Linier Berganda Dengan Menggunakan Data Panel 
Untuk mengetahui pengaruh upah minimum, jumlah industri pengolahan, dan output industri pengolahan terhadap ketimpangan penyerapan tenaga kerja sektor industri pengolahan di Kabupaten/Kota Jawa Timur dengan menggunakan analisis regresi linier berganda menggunakan bantuan software Eviews 6. Data yang digunakan merupakan panel data yaitu gabungan cross-section dan time series dengan observasi 5 tahun dari tahun 2008 sampai dengan 2012 yang terdiri dari 38 Kabupaten/Kota di Provinsi
Timur total observasi sebanyak 190 dan hal ini memenuhi syarat untuk dilakukan analisis regresi linier berganda. Dari hasil pengolahan data, model yang baik digunakan yaitu common effect.

\section{a. Interpretasi Model}

Berdasarkan pengujian model, model common effect merupakan yang paling baik digunakan dalam penelitian ini. Dengan menggunakan bantuan software eviews 6, diperoleh hasil output regresi panel data dengan metode common effect sebagai berikut:

\section{Tabel 2. Output Regresi dengan Metode Common Effect}

\begin{tabular}{crrrl}
\hline Variable & Coefficient & Std. Error & t-Statistic & Prob. \\
\hline C & -26.39723 & 6.231576 & -4.236044 & 0.0000 \\
X1? & 2.998944 & 0.990516 & 3.027658 & 0.0028 \\
X2? & 2.680185 & 0.190240 & 14.08845 & 0.0000 \\
X3? & 0.589090 & 0.212350 & 2.774147 & 0.0061 \\
\hline
\end{tabular}

Sumber: Data diolah menggunakan eviews 6, 2016. Maka diperoleh estimasi persamaan regresi sebagai berikut:

$\mathrm{Y}=-\beta \mathrm{o}+\beta_{1} X_{1}+\beta_{2} X_{2}+\beta_{3} X_{3}+\mathrm{e}$

$\mathrm{Y}=-26.39723+2.998944 \mathrm{X} 1+$

\section{$2.680185 \times 2+0.589090 \times 3+e$}

Dimana :

Y= Indeks Ketimpangan Penyerapan

Tenaga Kerja Sektor Industri

Pengolahan

$\mathrm{X} 1=\mathrm{Upah}$ Minimum

$\mathrm{X} 2=$ Jumlah Industri Pengolahan

X3= Output Industri Pengolahan

$\mathrm{e}=$ eror

\section{Konstanta atau intersep}

Menunjukkan bahwa apabila terdapat faktor upah minimum (X1), jumlah industri pengolahan (X2) dan output industri pengolahan (X3) maka ketimpangan penyerapan tenaga kerja sektor industri pengolahan sebesar 26.39723 dengan asumsi yang lain adalah konstan. Artinya apabila indeks ketimpangan naik sebesar $1 \%$ 
maka upah minimum, jumlah industri pengolahan dan output industri pengolahan juga naik sebesar 26.39723 .

\section{Pengaruh Upah Minimum Terhadap}

Indeks Ketimpangan Penyerapan

\section{Tenaga Kerja Sektor Industri} Pengolahan (X1)

Menunjukkan bahwa faktor upah minimum (X1) berpengaruh positif dan signifikan terhadap indeks ketimpangan penyerapan tenaga kerja sektor industri pengolahan di Kabupaten/Kota Jawa Timur dengan koefisien regresi sebesar 2.998944, artinya apabila upah minimum dinaikkan sebesar $1 \%$ maka akan menyebabkan ketimpangan penyerapan tenaga kerja sektor industri pengolahan di Kabupaten/Kota Jawa Timur mengalami kenaikan pula sebesar 3\%.

Pengaruh Jumlah Industri Pengolahan Terhadap Indeks Ketimpangan Penyerapan Tenaga Kerja Sektor Industri Pengolahan (X2)

Menunjukkan bahwa jumlah industri pengolahan(X2) berpengaruh signifikan dan positif terhadap ketimpangan penyerapan tenaga kerja sektor industri pengolahan dengan koefisien regresi sebesar 2.680185, artinya apabila jumlah industri dinaikkan sebesar $1 \%$ maka ketimpangan penyerapan tenaga kerja sektor industri pengolahan di Kabupaten/Kota Jawa Timur akan mengalami kenaikan sebesar 2.680185 atau 3\% dengan asumsi variabel bebas lainnya adalah konstan.

Pengaruh Output Industri Pengolahan Terhadap Indeks Ketimpangan Penyerapan Tenaga Kerja Sektor Industri Pengolahan (X3)

Menunjukkan bahwa output industri pengolahan (X3) berpengaruh signifikan dan positif terhadap ketimpangan penyerapan tenaga kerja sektor industri pengolahan dengan koefisien sebesar 0.589090 dapat diartikan apabila output industri pengolahan dinaikkan $1 \%$ maka ketimpangan penyerapan tenaga kerja sektor industri pengolahan di Kabupaten/Kota Jawa Timur akan mengalami kenaikan sebesar 0.589090 atau $1 \%$ dengan asumsi variabel bebas lainnya adalah konstan.

b. Uji Statistik dan Pengujian Hipotesis

Uji T Variabel Upah Minimum (X1) Hipotesis:

H0 $: \beta 1=\beta 2=0$

H1 $: \beta 1 \neq \beta 2 \neq 0$ 
Keriteria pengujian:

$\mathrm{H} 0$ diterima jika $\mathrm{T}_{\text {hitung }}<\mathrm{T}_{\text {tabel }}$

$\mathrm{H} 1$ diterima jika $\mathrm{T}_{\text {hitung }}>\mathrm{T}_{\text {tabel }}$

$\mathrm{T}_{\text {hitung }}=3.027658$

$\mathrm{T}_{\text {tabel }}=1.65304$

Berdasarkan hasil pengamatan diketahui bahwa $\mathrm{T}_{\text {hitung }}(3,027)>\mathrm{T}_{\text {tabel }}$ $(1,653)$ dengan demikian $\mathrm{H} 1$ diterima karena $\mathrm{T}_{\text {hitung }}$ tidak berada diantara 1,653 sampai 1,653yang merupakan daerah H0 diterima, artinya bahwa variabel Upah Minimum (X1) signifikan dan positif mempengaruhi Indeks Ketimpangan Penyerapan Tenaga Kerja Sektor Industri pengolahan (Y) pada tingkat kepercayaan $95 \%$.

Uji T Variabel Jumlah Industri

\section{Pengolahan (X2)}

Hipotesis:

H0 $: \beta 1=\beta 2=0$

H1 $: \beta 1 \neq \beta 2 \neq 0$

Keriteria pengujian:

$\mathrm{H} 0$ diterima jika $\mathrm{T}_{\text {hitung }}<\mathrm{T}_{\text {tabel }}$

$\mathrm{H} 1$ diterima jika $\mathrm{T}_{\text {hitung }}>\mathrm{T}_{\text {tabel }}$

$$
\begin{aligned}
& \mathrm{T}_{\text {hitung }}=14.08845 \\
& \mathrm{~T}_{\text {tabel }}=1.65304
\end{aligned}
$$

Berdasarkan hasil pengamatan data diatas diketahui bahwa $\mathrm{T}_{\text {hitung }}(14,088)>$ $\mathrm{T}_{\text {tabel }}(1,653)$ dengan demikian $\mathrm{H} 1$ diterima karena $\mathrm{T}_{\text {hitung }}$ tidak berada diantara $-1,653$ sampai 1,653 yang merupakan daerah $\mathrm{H} 0$ diterima, artinya bahwa variabel Jumlah Industri Pengolahan (X2) signifikan dan positif mempengaruhi Indeks Ketimpangan Penyerapan Tenaga Kerja Sektor Industri pengolahan (Y) pada tingkat kepercayaan $95 \%$.

\section{Uji T Variabel Output Industri}

\section{Pengolahan (X3)}

Hipotesis:

H0 $: \beta 1=\beta 2=0$

H1 $: \beta 1 \neq \beta 2 \neq 0$

Keriteria pengujian:

$\mathrm{H} 0$ diterima jika $\mathrm{T}_{\text {hitung }}<\mathrm{T}_{\text {tabel }}$

$\mathrm{H} 1$ diterima jika $\mathrm{T}_{\text {hitung }}>\mathrm{T}_{\text {tabel }}$

$\mathrm{T}_{\text {hitung }}=2.774147$

$\mathrm{T}_{\text {tabel }}=1.65304$

Berdasarkan hasil pengamatan data diatas diketahui bahwa $\mathrm{T}_{\text {hitung }}(2,774)>$ $\mathrm{T}_{\text {tabel }}(1,653)$ dengan demikian $\mathrm{H} 1$ diterima karena $\mathrm{T}_{\text {hitung }}$ tidak berada diantara $-1,653$ sampai 1,653 yang merupakan daerah $\mathrm{H} 0$ diterima, artinya bahwa variabel Output Industri Pengolahan (X3) signifikan dan positif mempengaruhi Indeks Ketimpangan Penyerapan Tenaga Kerja Sektor Industri pengolahan $(\mathrm{Y})$ pada tingkat kepercayaan $\quad 95 \%$. 
c. Uji F (F-test)

Tabel 3 Uji F (F-test)

\begin{tabular}{lrll}
\hline \hline R-squared & 0.592906 & Mean dependent var & 1.691153 \\
Adjusted R-squared & 0.586340 & S.D. dependent var & 2.142675 \\
S.E. of regression & 1.378091 & Akaike info criterion & 3.500103 \\
Sum squared resid & 353.2391 & Schwarz criterion & 3.568462 \\
Log likelihood & -328.5098 & Hannan-Quinn criter. & 3.527794 \\
F-statistic & 90.29908 & Durbin-Watson stat & 0.145570 \\
Prob(F-statistic) & 0.000000 & & \\
\hline \hline
\end{tabular}

Sumber: Data diolah menggunakan eviews 6, 2006.

$\mathrm{F}_{\text {hitung }}=90.29908$

$\mathrm{F}_{\text {tabel }}=3,04$

Berdasarkan hasil pengamatan data diatas diketahui bahwa $F_{\text {hitung }}$ $(90,29) \quad>F_{\text {tabel }} \quad(3,04) \quad$ dengan demikian $\mathrm{H} 1$ diterima karena $\mathrm{F}_{\text {hitung }}$ lebih besar dari nilai $\mathrm{F}_{\text {tabel, }}$ artinya bahwa variabel Upah Minimum (X1), Jumlah Industri Pengolahan (X2), Ouput Industri Pengolahan secara bersama-sama signifikan mempengaruhi Indeks Ketimpangan penyerapan Tenaga Kerja Sektor Industri Pengolahan (Y) pada tingkat kepercayaan $95 \%$.

\section{d. Uji Koefesien Determinasi $\mathbf{R}^{2}$}

Uji koefisien determinasi $\mathrm{R}^{2}$ dilakukan untuk mengetahui seberapa jauh variabel bebas ( Upah Minimum, Jumlah Industri dan Ouput Industri) mampu menjelaskan variabel terikat
(Indeks Ketimpangan Penyerapan Tenaga Kerja Sektor Industri Pengolahan).

Sesuai pengamatan dan perhitungan yang terdapat pada tabel maka dapat diperoleh nilai $R^{2}=$ 0,586340 yang berarti bahwa $58,63 \%$ Indeks Ketimpangan Penyerapan Tenaga Kerja Sektor Industri Pengolahan dapat menjelaskan secara bersama-sama oleh Upah Minimum, Jumlah Industri Pengolahan dan Output Industri Pengolahan, sisanya $42,37 \%$ dipengaruhi oleh faktor-faktor di luar model.

\section{KESIMPULAN}

Berdasarkan hasil penelitian dan perhitungan diambil kesimpulan sebagai berikut : 
Indeks Entropi Theil pada tahun 2008-2012 terdapat ketimpangan penyerapan tenaga kerja sektor industri pengolahan di Kabupaten/kota Jawa Timur. Pada tahun 2008 ketimpangan yang terjadi sebesar 1,67 dan pada tahun 2009 yaitu 1,67. Dan pada tahun 2010 dan 2011 memiliki ketimpangan yang sama yaitu sebesar 1,69. Sedangkan pada tahun 2012 mengalami penurunan yaitu sebesar 1,68 .

Dari hasil pengujian bahwa variabel lupah minimum (X1), jumlah industri pengolahan (X2) dan output industri pengolahan (X3) berpengaruh signifikan dan berhubungan positif terhadap indeks ketimpangan penyerapan tenaga kerja sektor industri pengolahan di kabupaten/kota Jawa Timur cocok menggunakan analisis data panel dengan model common effect.

\section{DAFTAR PUSTAKA}

Arsyad, Lincolin. 2010. Ekonomi Pembangunan, Yogyakarta: UPP STIM YKPN

Badan Pusat Statistik. 2003. Provinsi Jawa Timur

Badan Pusat Statistik. Provinsi Jawa Timur dalam angka 2009-2013.
Dinas Perindustrian Dan Perdagangan. 2011. Provinsi Jawa Timur

Dinas Tenaga Kerja Transmigrasi Dan Kependudukan. 2013. Jawa Timur

Gudjarati D. 2004.Ekonometrika Dasar. Zain Sumarno dan Zein [penerjemah]. Jakarta: Erlangga.

Haryani, Sri. 2002. Hubungan Industrial Di Indonesia. Yogyakarta : AMP YKPN

Kuncoro, Mudrajad. 2004. Metode Riset Untuk Bisnis dan Ekonomi, Penerbit Erlangga, Jakarta

Subekti, Mohamad A. 2007. Pengaruh Upah, Nilai Produksi, Nilai Investasi Terhadap PenyerapanTenaga Kerja pada Industri Kecil Genteng di Kabupaten Banjarnegara. Skripsi.Fakultas Ekonomi: Universitas Negeri Semarang.

Sukirno, Sadono .1985, Ekonomi Pembangunan : Proses, Masalah dan Dasar Kebijakan, Bima Grafika

Sukirno, Sadono. 2000. Makro Ekonomi Modern : Perkembangan Pemikiran dari Klasik Hingga Keynesian Baru. Jakarta: PT. Raja Grafindo Persada.

Suharto. 2002. Disparitas Dan

Pola Spesialisasi Tenaga Kerja

Industri Regional 1993-1996 Dan

Prospek Pelaksanaan Otonomi. 
Analisis Ketimpangan Penyerapan Tenaga Kerja...........(Wahyuni Aprilia)

Jurnal Ekonomi Pembangunan hal

$33-44$ 